\title{
INDIAN TRIBES IN IOWA BEFORE 1846.
}

\author{
BY DR. J, L. PICKARD.
}

The Territory first known as Iowa embraced all that is within its present limits and a large part of Minnesota- the St. Peters River being its northernmost limit. If, as it is claimed by some, Iowa means "Beautiful Land," the fact must have suggested the name. A broad expanse of billowy land, washed upon either side by navigable rivers, its crests a feeding ground for immense herds of buffalo and deer, its hollows the nestling place of lakelets filled with choicest fish-the lakelets strung like pearls upon silvery cords over which canoes could glide, lakelets and streams set in a rich framework of trees and shrubbery, a covert for the more timid wild animals and a nesting place for wild fowl - such an expanse was indeed an ideal hunting ground for the Red Man.

Paleontologists tell us that as the "ice age," which for time unknown held this territory in its grasp, yielded its sway, close upon its glacial border there lived a race of low-statured, low-browed men-similar to, perhaps identical with, the Esquimaux of the far north. A race superior to them followed them in their northward movement, and left in mounds and in the relics deposited therein evidences, in some degree, of civilization equal to that of the Aztec race. Such mounds are found in the northern and eastern parts of Iowa, though less numerous than in portions of the Mississippi Valley farther eastward.

The "Mound Builders" were not permitted to retain occupancy of their rich possessions, after the eyes of wilder 


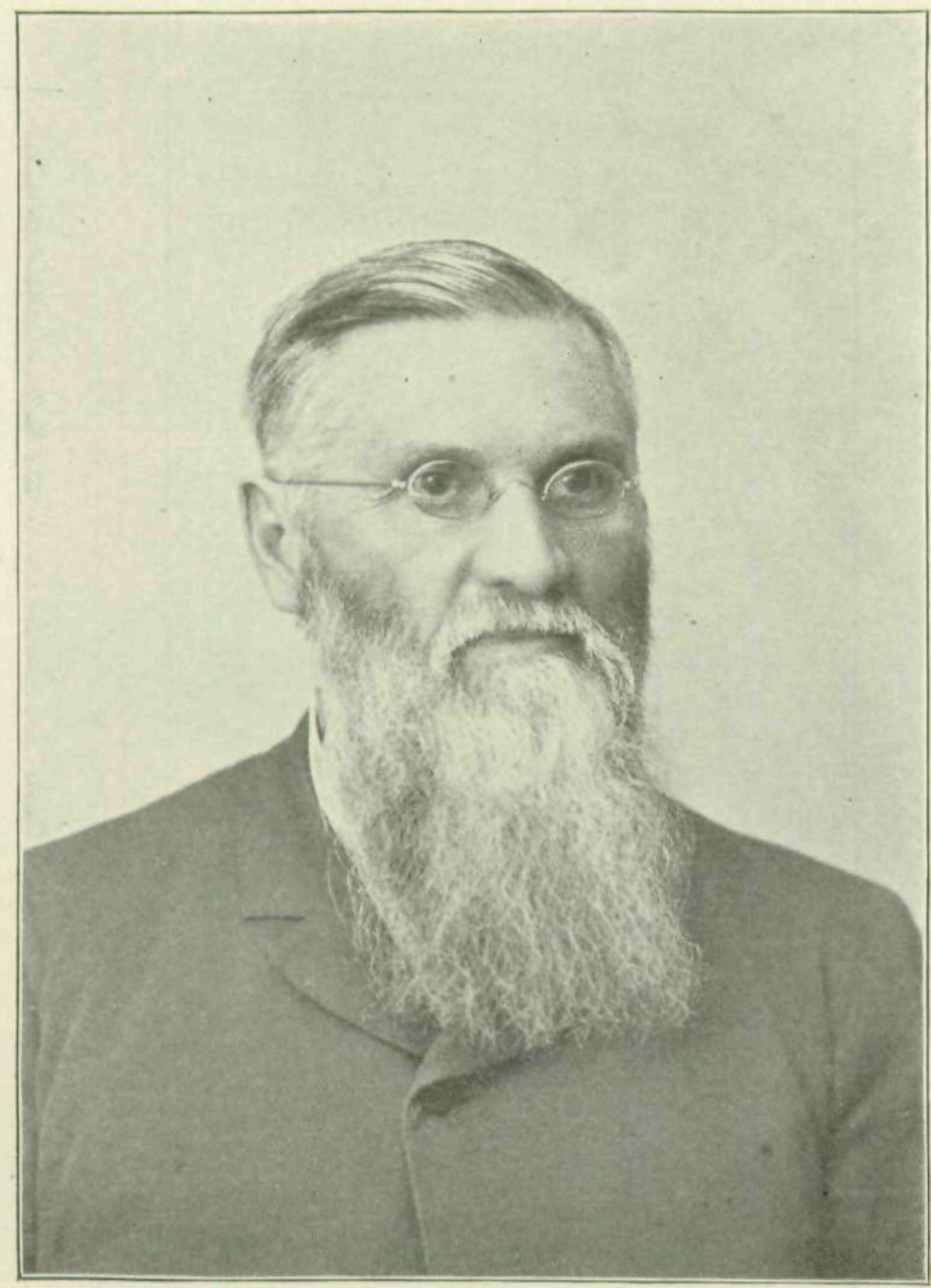

Fi. Rekeard 1893 
and more energetic tribes had rested upon them. Savage hordes from the great Algonquin family poured in by the way of the river St. Lawrence and the great lakes. A still more savage horde of Dacotahs (Nadessioux, Sioux) crossing the Rocky Mountains poured down the tributaries of the Missouri and the Missouri valley. Both streams were checked as they met upon the Upper Mississippi and turned southward. The Algonquins moving west rapidly, flanked the Sioux and crossed the Mississippi covering the territory south of a line extending from the mouth of the Little Iowa river to the mouth of the Calumet (Big Sioux) river.

That the Mound Builders did not surrender their lands without attempted defense is shown by a line of ruined fortifications, a notable instance of which is seen in Aztalan (Aztecland?) Wisconsin.

The Dacotahs oceupied that portion of Iowa territory now known as Minnesota and Northern Iowa. The Algonquins held possession of the remaining part of Iowa and of Northern Missouri.

At first rivals for the possession of the fair hunting grounds, the Dacotahs and the Algonquins at a later time became bitter foes.

It is useless to inquire when the change of occupancy occurred, or when the bitter enmity of the two hordes who had dispossessed the Mound Builders had its origin. It may have been centuries before the earliest records obtainable.

Icelandic records prove that Norsemen, fleeing from the tyranny of Harald, in the latter part of the ninth century, landed upon Iceland - that in the tenth century their descendants touched Greenland - that in the first years of the eleventh century a movement southward as far as Cape Cod was made - and that all along the Atlantic coast tribes of the Algonquin family were found.

Then comes a period of nearly five centuries of un- 
broken silence. The Norsemen had found America, but it was left for Columbus to discover the Western Continent.

During the last years of the fifteenth century and the first years of the sixteenth century discoveries were abundant.

No part of the continent discovered was without inhabitants. The Red Men were in undisputed possession until the white men claimed title by discovery. Traffic with the Indians was so profitable that French traders pushed their way up the St. Lawrence-English traders moved inward from the Atlantic sea board-Spanish traders entered the trading grounds from the south and the west.

The trade consisted largely in furs and in fish-articles of greatest value in the colder regions. Hence most is known of the Algonquin Indians of the northeast, and of the Dacotahs of the northwest. To the tribes of these great families found upon Iowa soil we will now confine ourselves.

Of the Algonquin family the tribes known to Iowa history are Sauks, Foxes, Illinois, Pottawattamies, Ottoways and Chippeways.

Of the Dacotah family-Sissetons, Iowas, Winnebagoes, Osages, Ottoes, Missouris and Omahas.

\section{ILLINOIS.}

The first Indians seen by white men on Iowa soil, so far as records go, were Illinois. Marquette and Joliet descending the Mississippi river in 1673 saw, about sixty leagues below the mouth of the Wisconsin river, human footprints in the mud upon the bank. Following these tracks six miles back from the river, they found a band of Illinois, at a point probably west of Montrose in Lee county, on the Des Moines river. 
After the failure of Pontiac's conspiracy, organized in the interests of France during the French and Indian war, he was assassinated by an Illinois in 1769 . His followers, chief among them Sauks and Foxes, waged a war of extermination against the Illinois and after 1803 the tribe was virtually extinct.

\section{DACOTAHS, (NADESSIOUX, SIOUX.)}

Father Hennepin was held a prisoner by Dacotahs for five months in 1680 and formed the acquaintance of De Luth.

\section{IOWAS, (AIOUEZ.)}

In 1700 Le Sueur reports seeing some of this tribe accompanied by Winnebagoes in the Blue Earth region, now Southern Minnesota. They had a tradition that long before the coming of the French they had left the Sioux family and were residing upon Lake Pepin-that while there the Winnebagoes, the Omahas and the Missouris, seceded and organized distinct bands; the Winnebagoes remaining near them, the Omahas and Missouris going southward and occupying western and southern Iowa, extending also into Missouri and Nebraska.

A band of Iowas passed southeastward and was found near Peoria in 1775 , but the main body came down the Rock river with the Winnebagoes and then passed down the Mississippi river to the mouth of the Des Moines river, stopping for a time in what is now Davis, Wapello and Van Buren counties, they moved across to the Missouri river, up that river to Mandan Village, then returning down the Missouri river they crossed southwestern Iowa and northern Missouri to the mouth of Salt river, then passed up the Mississippi and Des Moines rivers and had headquarters in Mahaska county. 


\section{SAUKS AND FOXES.}

These tribes, closely related, moved westward before the French(to whom they were then inimical), were pressed southward by the Ottaways and Chippeways who were in alliance with the French, and by the Sioux who were bitter enemies to all the Algonquin tribes; and about 1734 they crossed the Mississippi somewhere between Prairie du Chien and Dubuque. They then held territory upon both sides of the Mississippi, the Sauks being largely upon the eastern side, the Foxes calling themselves Musquakies, holding the lands about the lead mines of Dubuque, part of which they sold to Julian Dubuque in 1788. The Sauks crossed the Mississippi and established villages at the head of the Des Moines Rapids in Iowa and near the mouth of the Upper Iowa river. So Lient. Pike (U. S. A.) reports in 1805 . He also reports villages of Foxes twelve miles west of Dubuque, near the mouth of Turkey river, and six miles above Rock Rapids on the Iowa side.

MANDANS.

By tradition they were driven out to sea from the coast of Wales and were landed within the Gulf of Mexico and passed up the Mississippi river and the Missouri river among the Sioux. They showed a higher degree of civilization than the Sioux by the structure of their huts and by the permanence of their abodes.

Having thus far touched briefly upon all that can be gathered from tradition and from reports of travelers previous to the acquisition of Louisiana Territory from France, we are able to tread upon firmer ground in following the course of treaties made between the United States and the Indian tribes upon Iowa soil.

For convenience of treatment three distinct periods of treaty-making are noted: 
1. From the Revolution to the War of 1812.

2. From the War of 1812 to the Black Hawk War.

3. From the Black Hawk War to 1846.

Each of these periods will be followed in considering, 1st, The Algonquin Indians.

2d, The Dacotah or Sioux Indians.

The Iowas and the Winnebagoes, originally of the Sioux family, are found in such close alliance with the Algonquin family that they may be considered as virtually belonging to the latter.

FIRST PERIOD, 1778-1812.

The first movement westward is seen in a treaty Jan. 21,1785 , by which Ottaways and Chippeways agree to their eastern limit - as a line nearly due south from the mouth of the Cuyahoga river in Ohio.

Jan. 9, 1789. Pottawattamies and Sauks accept the same boundary.

August 3, 1795, Ottaways, Chippeways and Pottawattamies, join other tribes (with whom they had made common cause in western Ohio and had been defeated by General Anthony Wayne) in a treaty of confirmation of the eastern boundary previously fixed, of cession of several small reservations, and of grant of right of way to the United States either by land or water through their lands for the purpose of connection of the various military posts at Detroit, Fort Wayne, and as far west as the Mississippi river at the mouth of the Illinois river.

By treaty of Nov. 3, 1804, ratified Jan. 25, 1805, the Sauks and Foxes cede to the United States their lands east of the Mississippi river, retaining the privilege of residence until these lands should be sold to settlers. When thus sold the Indians are to remove west of the river, joining those of their tribes already upon Iowa soil.

Peculiar features of this treaty need brief explanation, since portions of the allied tribes under Black Hawk 
always denied its validity, and made it a part of the causes leading to the Black Hawk War. It was the custom of the tribes, either by vote to instruct their delegates in advance of their action, or to confirm by subsequent vote any actions had outside of their instructions. The delegates sent to St. Louis at the time of this treaty had definite instructions as to their duty, among which cession of lands was not included. The Black Hawk followers refuse to confirm this unwarranted surrender of their lands, but in 1815 and again in 1816 consent to a confirmation of the treaty. During this period no treaties are made with the Sioux.

SECOND PERIOD, 1812-1832.

During the war with Great Britain, nearly all the tribes of the Algonquin family and of the Sioux family joined with Great Britain.

Part of the Sauks separate themselves from the allied tribes of Sauks and Foxes out of friendliness to the United States and remove to the Missouri River. By treaty of September 13,1815 , they agree to remain apart from the Sauks of Rock River, if paid their share of annuities promised by the treaty of 1804 .

During the war the Sauks and Foxes appear to have dissolved their alliance, since the Foxes make a separate treaty of peace September 14, 1815, affirming their loyalty and confirming the treaty of 1804 .

The Sauks of Rock River refuse to surrender their fealty to Great Britain after the treaty of Ghent, until May 13, 1816, whereby they make peace with the United States, confirm the treaty of 1804 and surrender stolen property.

The Sauks and Foxes reunited enter into a treaty August 4, 1824, whereby they cede to the United States the lands given the loyal Sauks, also all lands in northern 
Missouri, except the "Half Breed Tract" in southeastern Iowa between the Mississippi River and the Des Moines River, then in Missouri.

August 19, 1825, a general council is called at Prairie Du Chien, at which appear representatives of Sioux, Sauks and Foxes, Winnebagoes, Ioways, Ottaways, Chippeways, Pottawattamies and Menominies. Its purpose was to bring about a cessation of internecine wars carried on by rival claimants for the same territory.

The treaty made fixes a boundary line between the warring Sioux and Chippeways, also a line separating the Sioux from the Sauks and Foxes and Ioways. The latter line especially concerns the Iowa Indians. Beginning at the mouth of the upper Iowa river, it crosses the fork of the Red Cedar river in Black Hawk County, thence proceeds to the upper fork of the Des Moines river in Humboldt County, thence to the lower fork of the Big Sioux river in Plymouth County, thence down the Big Sioux to the Missouri river in Woodbury County. (The line from the fork of the Des Moines westward is made dependent upon the consent of the Yankton tribe of the Sioux, which consent is given in 1830). The Sauks and Foxes, chief claimants of the territory south of the above line, consent to the joint occupancy with them by the Ioways until such time as a proper division can be made. This division seems never to have been effected, but the Ioways gradually move westward, and near the close of this period they are found in south-western Iowa and upon the west side of the Missouri river. The Ottoes, a Sioux tribe, are granted the right to remain upon the south of the dividing line.

In 1828 President Adams proclaims lands east of the Mississippi river open to settlement, and crders the Sauks and Foxes to remove west of the river, according to treaty of 1804 . 
After five years experience of the futility of the attempt to separate hostile tribes by an imaginary line, and after a succession of troubles especially between the Winnebagoes and adjoining tribes, a treaty is made July 15, 1830, between the United States and the parties to the treaty of August 19, 1825, whereby the Sauks and Foxes and Ioways cede to the United States all lands south of the line of 1825 and west of a line drawn from the fork of the Des Moines river, extending largely along the ridge separating the valley of the Des Moines from the valley of the Missouri to the northern line of Missouri, with the understanding that tribes residing thereon should not be disturbed, and with the further understanding that other tribes might be located thereon at the pleasure of the United States. The Sioux cede to the United States a strip of land twenty miles wide, extending upon the north of the line of 1825 from the Mississippi river to the Des Moines river. The Sauks and Foxes and Ioways cede a like strip upon the south side of the said line between the same terminal points. This strip of land, forty miles in width, is designated as "Neutral Ground." In the early years of this period many treaties of peace and friendship are made with all the tribes occupying Iowa territory.

In 1819 the hitherto peaceful relations subsisting between the Sauks and Foxes and Ioways are rudely broken by the treacherous murder of a young Ioway by a Sauk, while hunting together. May 1, 1823, hostilities culminate in a battle near Iowaville, which resulted in the utter defeat of the Ioways, and they gradually move westward, tarrying for a time in Mahaska and neighboring counties. Before the close of the period the Sauks and Foxes had removed to the west side of the Mississippi; Black Hawk, however, had never been reconciled to the removal and returns in 1832 to cultivate the lands upon Rock River. 
THIRD PERIOD, 1832-1846.

After the planting Black Hawk starts upon a visit to his friends, the Winnebagoes. His surly mood had aroused the white settlers of Illinois, who organize a force against him, and in a brief campaign known as "The Black Hawk War," defeat his band and take their chief a prisoner through the treachery of his Winnebago allies. Public and private reasons Black Hawk urges for his course, which a calm judgment may in part approve. At the close of the war the Sauks and Foxes by treaty of September 21, 1832, cede to the United States a strip of territory beginning at a point upon the southern boundary of the "neutral territory," fifty miles from the Mississippi river, thence proceeding at about an average distance of forty miles from the river to a point on the northern boundary of Missouri fifty miles from the Mississippi river, thence in direct line to the river, thence by the river to the boundary of the "neutral territory," thence to the point of beginning, reserving a tract of four hundred square miles about "Keokuk Village," to be laid out in as nearly equal portions as possible upon either side of the Iowa river, also a section of land for Antoine Le Claire opposite Rock Island. September 27, 1836 , Sauks and Foxes cede all the lands then held in northwestern Missouri. Upon the next day they surrender the "Keokuk Village" reservation, and agree to allow to the Ioways their just share of the moneys received under the treaty of September 21, 1832.

October 31,1837 , a tract of land containing about $1,250,000$ acres is ceded, lying between the land ceded September 21, 1832, and a straight line connecting the northwest and the southwest points of the cession of 1832. This line is just west of the western boundary of Johnson county. By treaty of October 11, 1842, the Sauks and Foxes cede all their lands in Iowa, reserving the right to hunt for three years upon lands west of a line 
running north and south within eight miles of the junction of the White Breast Fork with the Des Moines River, not far from Fort Dodge.

October 19, 1838, the Ioways cede all their lands in Iowa. At this time they outnumbered the Sauks and Foxes and were in a good degree civilized.

September 15, 1832, the Winnebagoes cede lands in Wisconsin and Illinois and are granted a portion of the "neutral territory," containing 1,600 square miles. November 1, 1837, they surrender the eastern half of their lands in "neutral territory." In 1846 they accept lands upon the St. Peter's River in Minnesota and remove thither. The Pottawattamies come into Western Iowa between the years 1832 and 1835, and with the allied Ottaways and Chippeways, are given 5,000,000 acres in southwestern Iowa. In 1837 they accept lands west of the Missouri River and remove before 1846.

October 21, 1837, the Yankton Sioux, who were not a party to the treaty establishing the line of separation of August 19, 1825, surrender their claims to lands south of that line. When Iowa was admitted to the Union the main bodies of Indians had removed to the west of the Missouri river, except the Sioux, who had not ceded any lands north of the line of separation of 1825, and the Winnebagoes who went north into Minnesota. A few roving bands of Sioux remain in northwestern Iowa, but they are not in good standing with their tribes. A small band of Foxes, or Musquakies as they call themselves, remain in Tama county and are granted lands by the legislature of 1856 .

None of the various cessions sketched above were made without consideration. Cash in hand, annuities in money or merchandise, as preferred, investments bearing usually five per cent. annual interest, merchandise, blacksmith service, tools for cultivation of the land, domestic animals, teaching service, assumption of debts to 
traders, gifts to half-breeds, and various other gifts to the tribes, expenses of removal, are in part or in whole considerations named. Trading posts were also established.

Frequent instances of the Indian remembrance of their white and half-breed friends appear in the reservations made from their cessions, as in "Half Breed Tract," in Lee county, " Keokuk Village reservation in Wapello county, Le Claire reservation in Scott county, and the burial place of General Street near Agency City.

In the midst of treachery so commonly attributed to the Indian he still lives up to a code of honor. One instance may suffice. When the Ioway was treacherously murdered by a Sauk, Black Hawk found the criminal and was about to surrender him to the Ioways for punishment. Finding him too ill to go, a brother who offered himself as a substitute was accepted. In sight of the Ioway village Black Hawk dared go no farther, but the victim went on alone and surrendered himself. The Ioways were so struck with the magnanimity of the young brave, who was ready for the death which his brother had earned, that they released him and sent him back to his brother with a present of a pony.

* Made in honor of an army surgeon who had surrendered his commission rather than abandon his Indian wife.

"I entertain an high idea of the utility of periodical publications: insomuch that I could heartily desire copies of the Museum and Magazines, as well as common Gazettes, might be spread through every city, town and village in America. I consider such easy vehicles of knowledge more happily calculated than any other to preserve the liberty, stimulate the industry, and meliorate the morals of an enlightened and free people."-Washington to Matthew Carey, June 25, 1788. 
Copyright of Annals of Iowa is the property of State of Iowa, by \& through the State Historical Society of Iowa and its content may not be copied or emailed to multiple sites or posted to a listserv without the copyright holder's express written permission. However, users may print, download, or email articles for individual use. 